\title{
Ameliorative Effect of Omega-3 on Energy Drinks - Induced Pancreatic Toxicity in Adult Male Albino Rats
}

\section{Original Article}

\author{
Asmaa A. El Desouky, Ahmed Abo Zaid, Ghada H. El Saify and Dalia A. Noya \\ Department of Histology and Cell Biology, Faculty of Medicine, Menoufia University
}

\begin{abstract}
Background: The world wide increasing popularity of the energy drinks and the lack of information about their possible hazardous effects on health is a matter of controversy and research. The aim of this study is to assess the histological and histochemical effects of energy drinks on the pancreas of adult male albino rats and the possible protective effect of omega-3. Material and Methods: Fifty adult male albino rats were randomly divided into 4 groups. First group is control. Second group (Omega-3 treated) rats received omega-3 at a dose of $300 \mathrm{mg} / \mathrm{kg} / \mathrm{day}$ orally for 4 weeks. Third group (Red Bull treated) rats received Red Bull at a dose of $10 \mathrm{mg} / \mathrm{kg} / \mathrm{day}$ orally for 4 weeks then they were randomly subdivided into two equal subgroups: IIIA, rats were sacrificed after $24 \mathrm{~h}$ of the last dose and in IIIB (Recovery group), rats were sacrificed after 4 weeks of the last dose .Fourth group (Omega-3 and Red Bull treated group) rats received Red Bull at a dose of $10 \mathrm{mg} / \mathrm{kg} /$ day and Omega-3 at a dose of $300 \mathrm{mg} / \mathrm{kg} /$ day for 4 weeks. At sacrifice, blood samples were drawn for biochemical study and pancreas specimens were prepared for histological and histochemical study.

Results: Energy drink had no significant effect on the animal weight $(\mathrm{P}=0.055)$, but there was highly significant increase in the pancreatic weight $(P=0.001)$ and in mean blood glucose level $(\mathrm{P}=0.000)$. There were signs of $\beta$ cells overstimulation. Histological and histochemical study of the pancreatic sections revealed multiple deleterious effects of the energy drink on the acinar and the islet cells. These changes were reversible as shown in the recovery group. Co-administration of Omega-3 showed marked protection of the pancreatic acini and the islets of Langerhans.

Conclusion: Omega-3 administration has a highly protective effect on the pancreatic tissue against the hazardous effects of the energy drinks.
\end{abstract}

Received: 06 December 2018, Accepted: 21 January 2019

Key Words: Energy drink, insulin resistance, islets of langerhans, omega-3, pancreas.

Corresponding Author: Asmaa Aly El Desouky, MSc, Department of Histology and Cell Biology; Faculty of Medicine; Menoufia University, Egypt, Tel.: +20 1065942332, E-mail: dr.asmaa.aly@gmail.com

ISSN: 1110-0559, Vol. 42, No. 2

\section{INTRODUCTION}

Energy drinks are non-alcoholic, lightly carbonated beverages that are designed to give the consumer a dose of energy. Public consumption of energy drinks has greatly increased over the past decade with the majority of users being adolescents and adults less than 35 years of age ${ }^{[1]}$. There are different types of energy drinks, with names like Boom Boom, Power horse, Burn, Monster, Red Bull and AMP Energy. Energy drinks have sugar-containing and sugar-free versions. Red Bull is the most popular energy drink consumed in Egypt ${ }^{[2]}$. Energy drinks mostly contain caffeine, other plant based stimulants (guarana, ephedrine, yerba mate), sugars and their derivatives (glucose, fructose, sucrose, ribose and glucuronolactone; which is a naturally occurring glucose metabolite), amino acids (taurine, carnitine, creatine), other herbal extracts (ginseng, ginkgo biloba), maltodextrin, inositol, vitamin $\mathrm{B}$ complex and other ingredients ${ }^{[3]}$. According to the manufacturers, the stimulating effects of these drinks are due to interaction between the various ingredients. They claim that these drinks improve physical endurance, reaction speed and concentration $^{[4]}$. There are several studies recording a modest improvement of energy drinks consumption on physical endurance ${ }^{[5,6,7]}$, but also studies that showed no significant enhancement of endurance related to the consecutive energy drinks consumption ${ }^{[8]}$. Some of the compounds found in energy drinks are used in therapy for treating certain disorders, like taurine and niacin for dyslipidemias. Other compounds, like glucuronolactone, are not well studied. An alarming number of side effects and even deaths were reported, as a consequence of energy drinks consumption. Arrhythmia, cardiac arrest and hepatitis are some of the quoted side effects ${ }^{[9,10,11]}$.

Despite the popularity of these drinks, their effects on consumers' health are quite controversial and not sufficient research on energy drinks' safety has been conducted yet.

Omega-3 in Fish oil is one of the most important polyunsaturated fatty acids (PUFA) that have an antiinflammatory and an antioxidant activity ${ }^{[12]}$. It is a blend of two essential fatty acids: eicosapentaenoic acid (EPA) and docosahexaenoic acid (DHA) ${ }^{[13]}$. Also, recent studies 
suggested that dietary intake of Omega- 3 could be useful in prevention of diabetes; as it reduced the activity of the pro-inflammatory processes which stimulated the body to attack its own insulin producing cell[ ${ }^{[14]}$.

With energy drinks becoming a worldwide phenomenon, the short- and long-term effects of these beverages must be evaluated more closely in order to fully comprehend their impact on different body organs ${ }^{[15]}$. The aim of this study was to assess the effects of Red Bull as one of the most popular energy drinks on the pancreas of adult male albino rats and the possible protective effect of omega-3.

\section{MATERIAL AND METHODS}

\section{Drugs}

Energy drink ( Red Bull GmbH, 5330 Fushl am see, Austeria) is available in the Egyptian market in the form of cans $250 \mathrm{ml}$. Each $100 \mathrm{ml}$ containing: a mixture of water, sucrose, glucose, sodium citrate, carbon dioxide, taurine $(0.4 \%)$, caffeine $(0.03 \%)$, gluconolactone $(0.24 \%)$, inositol, niacin $(8 \mathrm{mg})$, pantothenic acid $(2 \mathrm{mg})$, vitamin B6 (2 mg), B12 (0.002 mg), caramel, riboflavin, natural and artificial flavoring and coloring agents (these are the labeled ingredients of the product company on the cans).

Omega-3 is available in the form of liquid syrub 120 $\mathrm{ml}$. composition per $5 \mathrm{ml}$ : high DHA Fish oil $640 \mathrm{mg}$, Rigel evening primrose oil $213 \mathrm{mg}$, Dl-alpha tocopherol acetate, thyme oil $0.40 \mathrm{mg}$, equivalent to vitamin E 7.82 mg. manufactured by Sigma pharmaceutical industries.

\section{Animals}

The present study was carried out in the Animal House of Faculty of Medicine, Menoufia University. It included 50 male albino rats weighting 200-250g. They were housed in four hygienic stainless steel cages and kept in clean well-ventilated room. They were allowed free access to water and fed ad libitium. Strict care and hygiene were taken to maintain normal and healthy environment for all rats all time. The general conditions and behavior of the animals were noticed. The animals were divided into four main groups:

Group I (control group): Included 10 animals received $2 \mathrm{ml}$ distilled water by oral route for 4 weeks.

Group II (omega-3 treated group): Included 10 animals. They received omega- 3 at a dose of $300 \mathrm{mg} / \mathrm{kg} /$ day orally for 4 weeks.

Group III (Energy drink treated group): Included 20 animals. They received Red Bull at a dose of $10 \mathrm{mg} / \mathrm{kg} / \mathrm{day}$ orally for 4 weeks ${ }^{[30]}$. Half the animals were sacrificed at the end of the period of treatment (Subgroup III A) and the other half were left for another 4weeks (Subgroup III B)

Group IV (Energy drink and Omega-3 group): Included 10 animals. They received Red Bull at a dose of $10 \mathrm{mg} / \mathrm{kg} /$ day and Omega-3 at a dose of $300 \mathrm{mg} / \mathrm{kg} /$ day for 4 weeks.

\section{Sampling, Sectioning and Staining}

All rats were weighed at the end. During the last day of the experiment, animals were deprived of food overnight then sacrificed by cervical dislocation. Blood samples were taken directly from the heart for biochemical assessment. The abdomen of the rats was opened, the pancreas was dissected out then perfused with cold saline, in $10 \%$ neutral buffered formalin overnight then processed to obtain paraffin blocks.Serial Paraffin sections of 5-6 $\mu \mathrm{m}$ thickness were cut and prepared for histological ( Hx \& E and Toluidine blue ) and histochemical (Mallory trichrome for detection of collagen and Gomori for illustration of B and $\alpha$ cells of pancreas) studies.

\section{Immunohistochemistry (IHC) assessment}

Some sections from all specimens (both control and treated) were picked upon coated slides for the immunohistochemical study which was done by peroxidase-labeled Streptavidin-Biotin technique using the anti-insulin antibody; insulin Ab-6 (INS04 + INS05) Mouse Monoclonal Antibody (Thermo Fisher Scientific, Fremont, CA, USA) which is a cocktail especially designed for sensitive detection of insulin.

\section{Morphometric study}

By using Image analyzer software (Image J $1.47 \mathrm{v}$ national institute of health, USA) we calculated the percentage area of connective tissue and the intensity of the brown color of anti-insulin immune expression.

\section{Statistical analysis}

Statistical analysis was performed using SPSS software, version 16.00 (Chicago, Illinois, USA). All data were expressed as mean $\pm \mathrm{SD}$. One-way analysis of variance (ANOVA) and post-hoc with least significant difference were used for comparison between groups. Significance was considered at $p<0.05$.

\section{RESULTS}

\section{I - statistical results}

\section{A) The body weight}

There was no significant change in the mean body weights of rats of all studied groups as compared to control group $(P>0.05)$. Also, no significant change in the mean body weights of rats of recovery group as compared to protected group $(P>0.05)$ (Table 1).

\section{B) The pancreatic weight}

There was significant increase in the mean pancreatic weight of treated group $(p<0.05)$, significant decrease in the mean pancreatic weight of the recovery group $(p<0.05)$ and no change in the mean pancreatic weight of Omega-3 group and protected group compared with animals of control group $(p>0.05)$. Highly significant decrease in the mean pancreatic weight of the recovery group compared to the protected group was observed $(p<0.001)$ (Table 2). 


\section{I- Biochemical changes}

\section{Blood Glucose level}

There was highly significant increase in mean blood glucose level in treated group and protected group compared to the control group $(p<0.001)$. While there was no significant change in mean blood glucose level of omega- 3 treated group and recovery group compared to control group $(p>0.05)$. Highly significant increase in mean blood glucose level was observed in protected group compared to recovery group $(p<0.001)$ (Table 3 and Diagram 1).

\section{II- Histological changes}

Group I and group II: Pancreatic sections of control and omega-3 treated groups were almost similar showing different sized lobules composed of serous acini with apical acidophilia and basal basophilia. Intact intra lobular ducts. Islets of Langerhans appeared as pale staining areas of polygonal cells arranged in clusters (Fig.1A, B) and (Fig.2A, B). There were abundant zymogen granules in acinar cytoplasm (Fig.3A,B).The lobules were separated by thin delicate connective tissue septae with deposition of minimal amount of collagen fibers around ducts and blood vessels (Fig.4A,B). Modified gomori aldehyde fuchsine stain showed normal intensely stained purple to violet beta cell filling the majority of the islet and alpha cells stained yellow (Fig.5A,B).

Group III (Energy drink treated group): Pancreatic sections of rats treated with energy drink for 4 weeks then sacrificed 24 hours after the last dose (subgroup IIIA) showed distorted archeticture with small atrophic acini and decreased apical acidophilia. Some nuclei were small pycnotic or even lost and the others showed perinuclear haloes. Ducts were dilated with retained secretions and lined by degenerated epithelium. There were dilated congested blood vessels. Some islets of Langerhans showed apparent increase in size with darkly stained nuclei and others showed degeneration with loss of cells and empty spaces (Fig.1C,D) and (Fig.2C,D). Zymogen granules were lost (Fig.3C). Pancreatic septae are thickened with increased amount of collagen fibers around ducts and blood vessels
(Fig.4C). Modified gomori aldehyde fuchsine stain showed depletion of the staining of beta and alpha cells of islets of Langerhans (Fig.5C).

Pancreatic sections of rats treated with energy drink for 4 weeks then left for 4 weeks without treatment (subgroup IIIB) showed some improvement in the form of restoration of the acinar architecture. Intralobular ducts and the islets of Langerhans appeared nearly normal. Some congested blood vessels were still present. Some nuclei became normal vesicular and others were still pyknotic (Fig.1E) and (Fig.2E). There was restoration of zymogen granules in acinar cytoplasm (Fig.3D). Pancreatic septae were still thickened with increased amount of collagen around ducts and blood vessels (Fig.4D). Modified gomori aldehyde fuchsine stain showed mild stained beta and alpha cells of islets of Langerhans (Fig.5D).

Group IV (Energy drink and Omega-3 group): pancreatic sections of this group revealed a noticeable protection of the acini against the deleterious changes induced by the energy drink. The ducts and the islets of Langerhans also appeared nearly normal. There were still dilated congested blood vessels (Fig.1F) and (Fig.2F). Zymogen granules were present in acinar cytoplasm (Fig.3E). Pancreatic septae was thin with deposition of minimal amount of collagen fibers around ducts and blood vessels (Fig.4E). Modified gomori aldehyde fuchsine stain showed normal intensely stained purple to violet beta cell and yellow stained alpha cells (Fig.5E).

\section{III- Immunohistochemical changes}

The anti-insulin monoclonal mouse primary antibody: Bothgroup I and group II (control and Omega-3 treated group) were similar showing moderately positive immune reaction (Fig.6A,B). Energy drink treated group for 4 weeks then sacrificed 24 hours after the last dose (subgroup IIIA) showed strongly positive immune reaction (Fig.6C). Energy drink treated group for 4 weeks then left for 4 weeks without treatment (subgroup IIIB) showed weak positive immune reaction (Fig.6D). Group IV (Energy drink and Omega-3 treated group) showed moderately positive immune reaction (Fig.6E). 

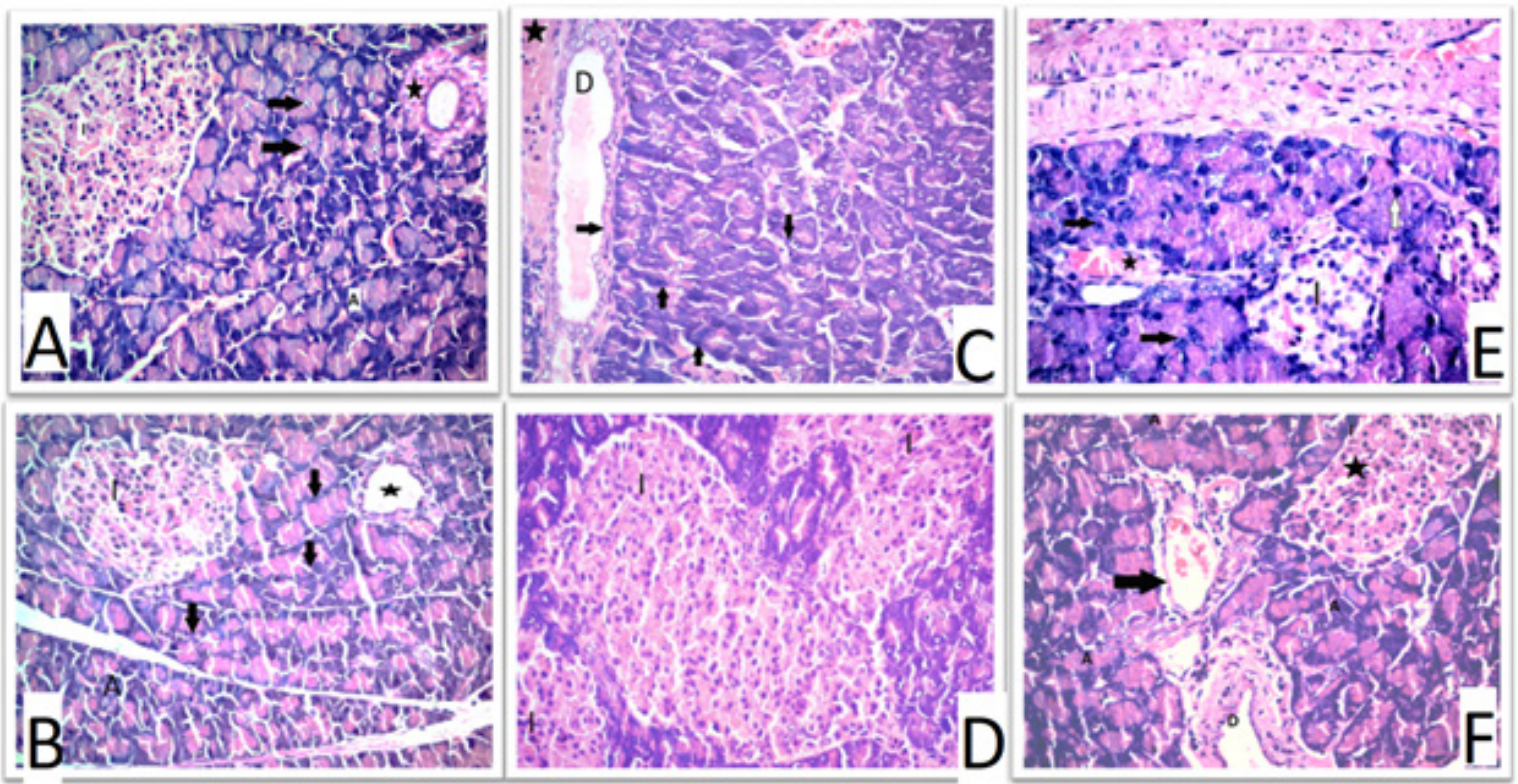

Fig. 1: Hx \& E stained pancreatic sections of :

(A) Control group and (B) Omega-3 treated group showing normal acinar architecture of closely packed acini (A) with central acidophilia and peripheral basophilia (arrow), normal intralobular ducts (star). Islets of Langerhans appear normal (I).

(C\&D) Energy drink treated group (subgroup III A) showing loss of normal acinar architecture, dilated duct with retained secretion and degenerated epithelium (C).Islets of Langerhans showing apparent increase of size with darkly stained nuclei (D).

(E)Recovery group (subgroup III B) showing restoration of the normal acinar architecture, normal intra lobular duct and islets of Langerhans. Dilated congested blood vessels are still present.

(F) Protected group showing normal acinar architecture and normal intra lobular duct. Islets of Langerhans also appear nearly normal (star). There are some congested blood vessels (arrow).

(H\&E x 400)
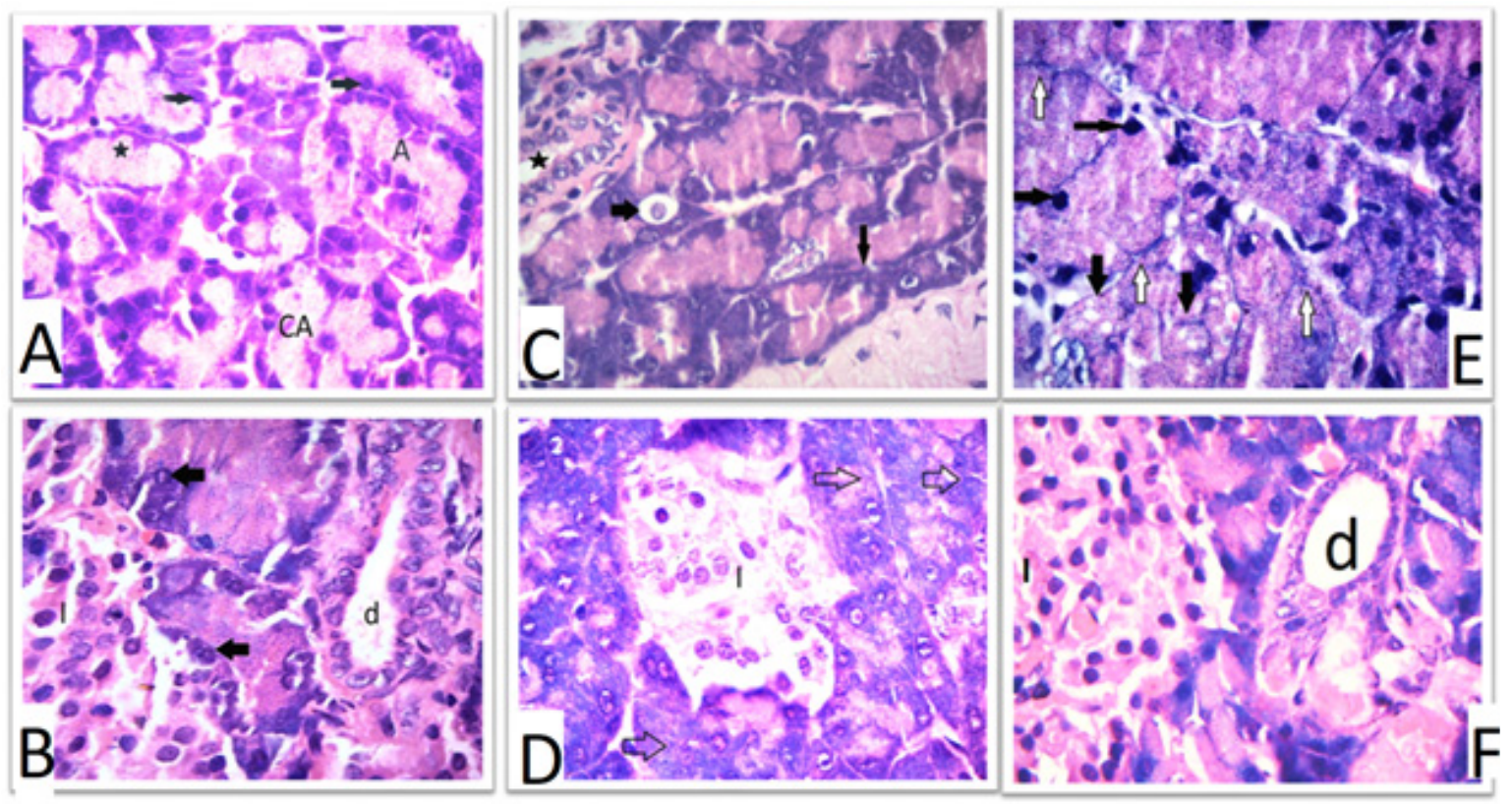

Fig. 2: Hx \& E stained pancreatic sections of :

(A)Control group and (B) Omega-3 treated group showing normal acini (A) with basal rounded vesicular nuclei. Also, Centro acinar cell appears (CA) with lightly stained rounded nucleus. Duct (d) appears normal lined by simple cubical epithelium. Islet of Langerhans (I) appears as cluster of polygonal cells. (C,D) Energy drink treated group (subgroup III A) showing irregular acini with some nuclei appear pyknotic or even lost, others show perinuclear vacculation (arrows). Islet of Langerhans shows empty spaces with loss of the nuclei (I).

(E) Recovery group (subgroup III B) showing loss of some nuclei and others are still pyknotic (arrow).

(F) Protected group showing normal pancereatic acini with basal rounded nuclei. Normal duct with simple cubical epithelium. Islet of Langerhans appears normal with cluster of polygonal cells.

(H\&E x 1000) 

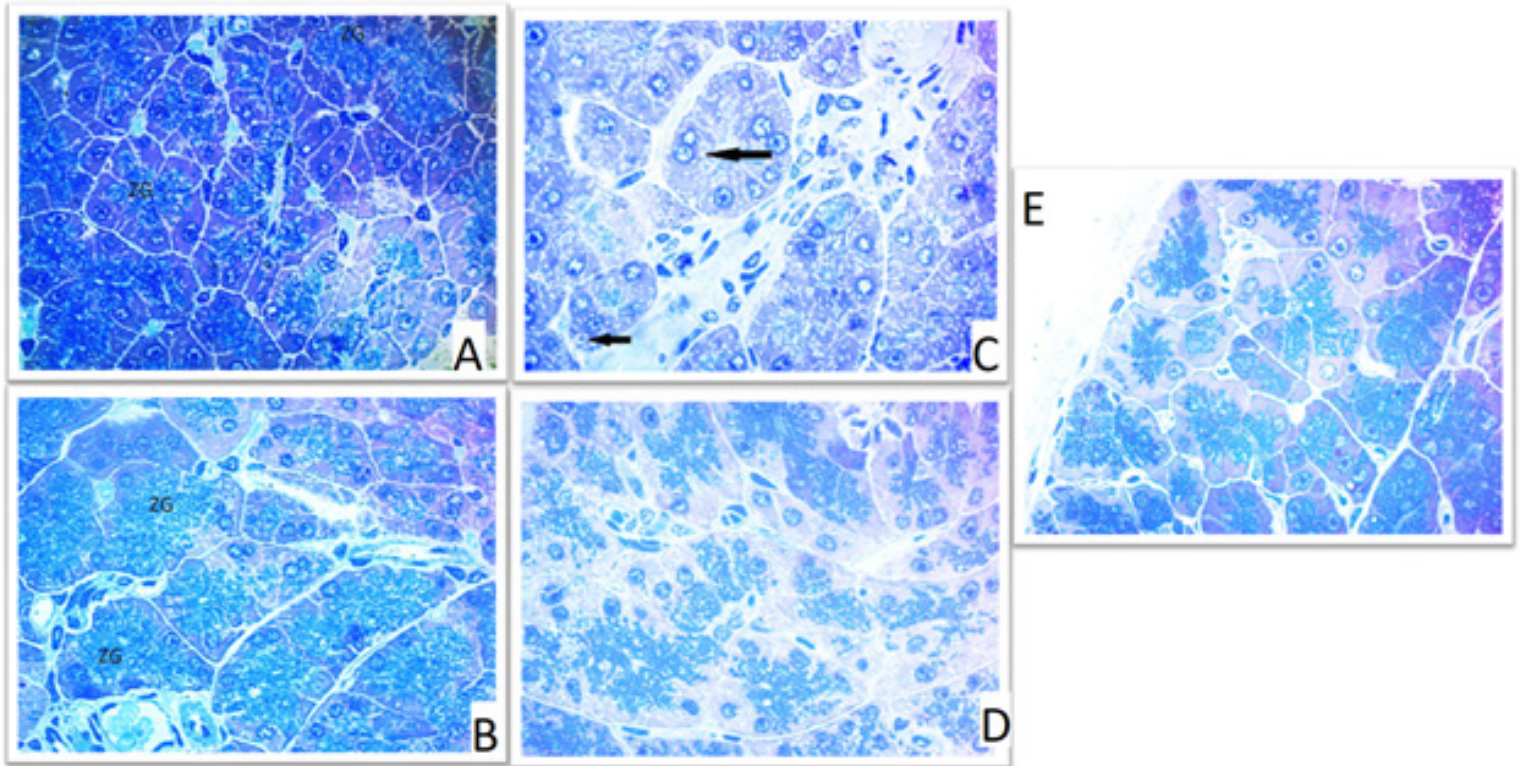

Fig. 3: Toluidine blue stained pancreatic sections of :

(A) control group and (B) Omega-3 treated group showing abundant zymogen granules in the apical part of the acinar pancreatic cells.

(C)Energy drink treated group (subgroup IIIA) showing apparent decrease of zymogen granules (arrow) and thickened connective tissue septae with cellular infiltration.

(D)Recovery group (subgroup III B) showing abundant zymogen granules in the acinar cytoplasm. The acini are of different in size.

(E)Protected group showing normal zymogen granules in the apical part of the pancreatic acini.

(Toluidine blue x1000)
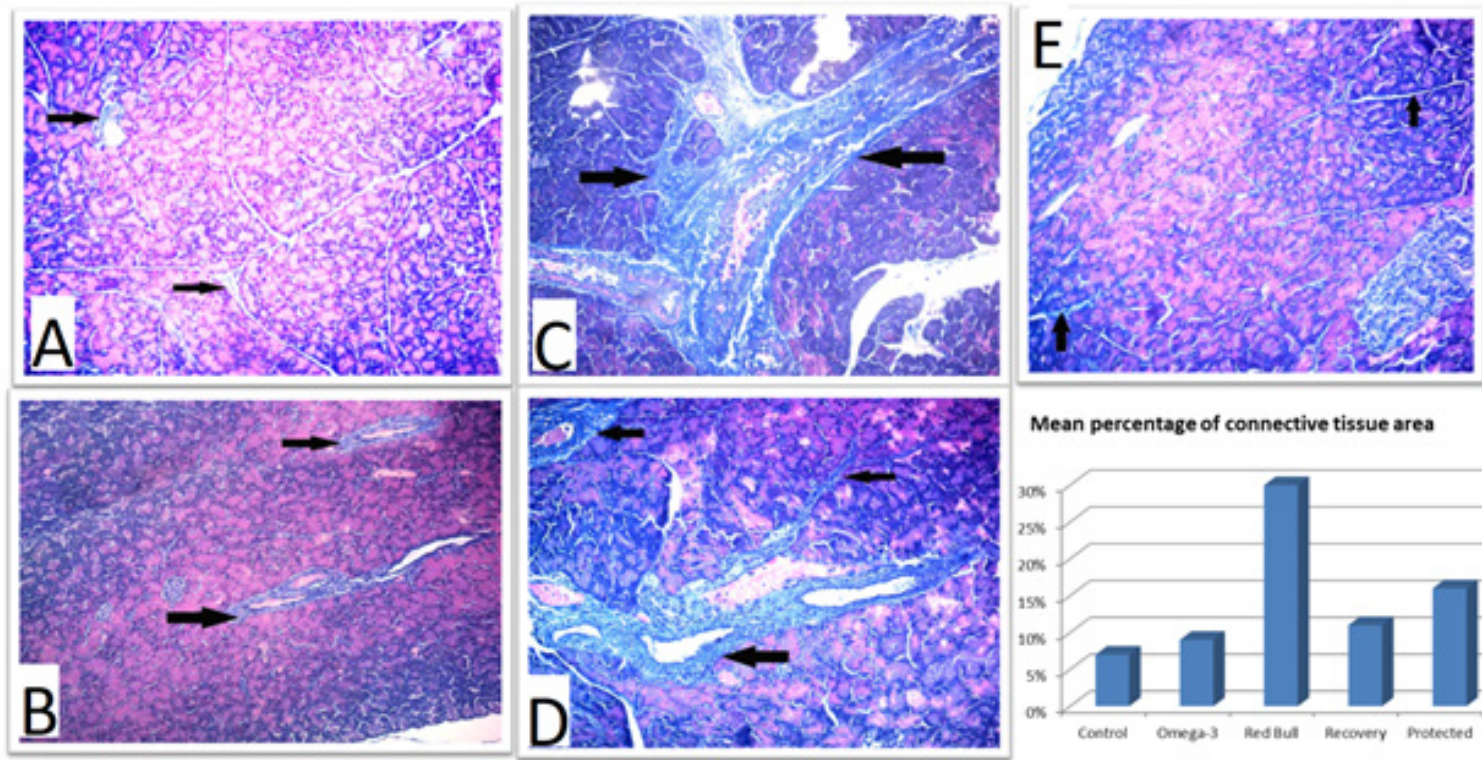

Mean percentage of connective tissue area

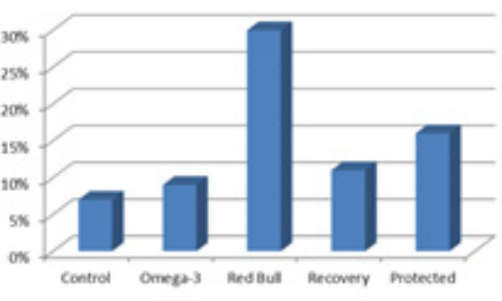

Fig. 4: Mallory trichrome stained pancreatic sections of :

(A) Control group and (B) Omega-3 treated group showing thin interlobular connective tissue septae with deposition of minimal amount of collagen fibers around the blood vessels and pancreatic duct (arrow).

(C)Energy drink treated group (subgroup III A) showing thickened interlobular connective tissue septae with deposition of large amount of collagen fibers around the blood vessels and pancreatic duct (arrow).

(D)Recovery group (subgroup III B) showing still thickened interlobular connective tissue septae and deposition of moderate amount of collagen fibers.

(E)Protected group showing thin interlobular connective tissue septae more or less the same like the control group.

( Mallory trichrome $\mathrm{x} 400$ ) 


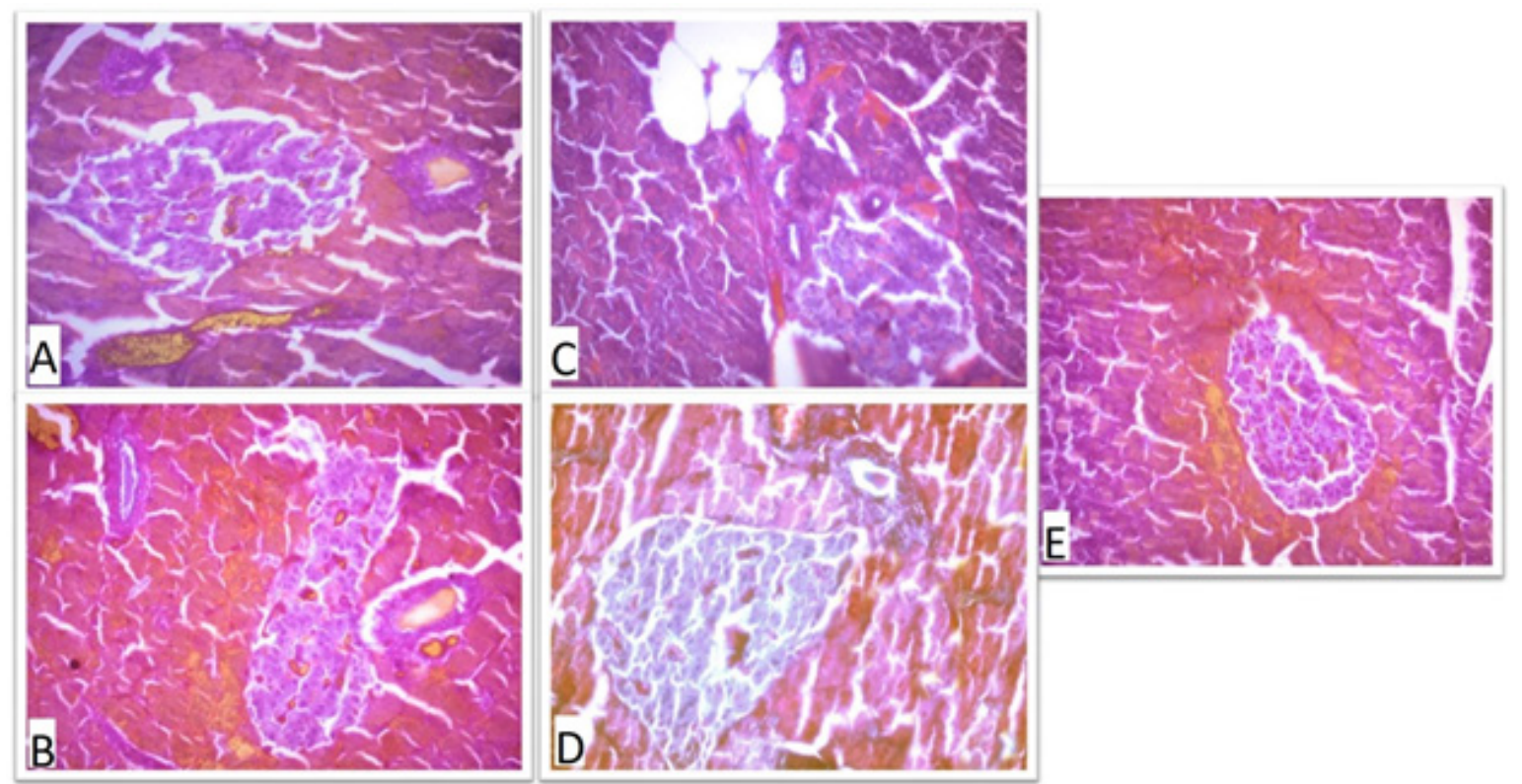

Fig. 5: Modified aldehyde fuchsine stained pancreatic sections of :

(A) Control group and (B) Omega-3 treated group showing intensely stained purple to violet Beta cells filling the majority of the islet and intensely stained yellow $\alpha$ cells.

(C) Energy drink treated group showing moderately stained Beta cells and $\alpha$ cells of the islet of Langerhans.

(D) Recovery group (subgroup III B) showing mild stained Beta and $\alpha$ cells of the islet of Langerhans.

(E)Protected group showing deeply stained granulated Beta cells (purple) and $\alpha$ cells (yellow).
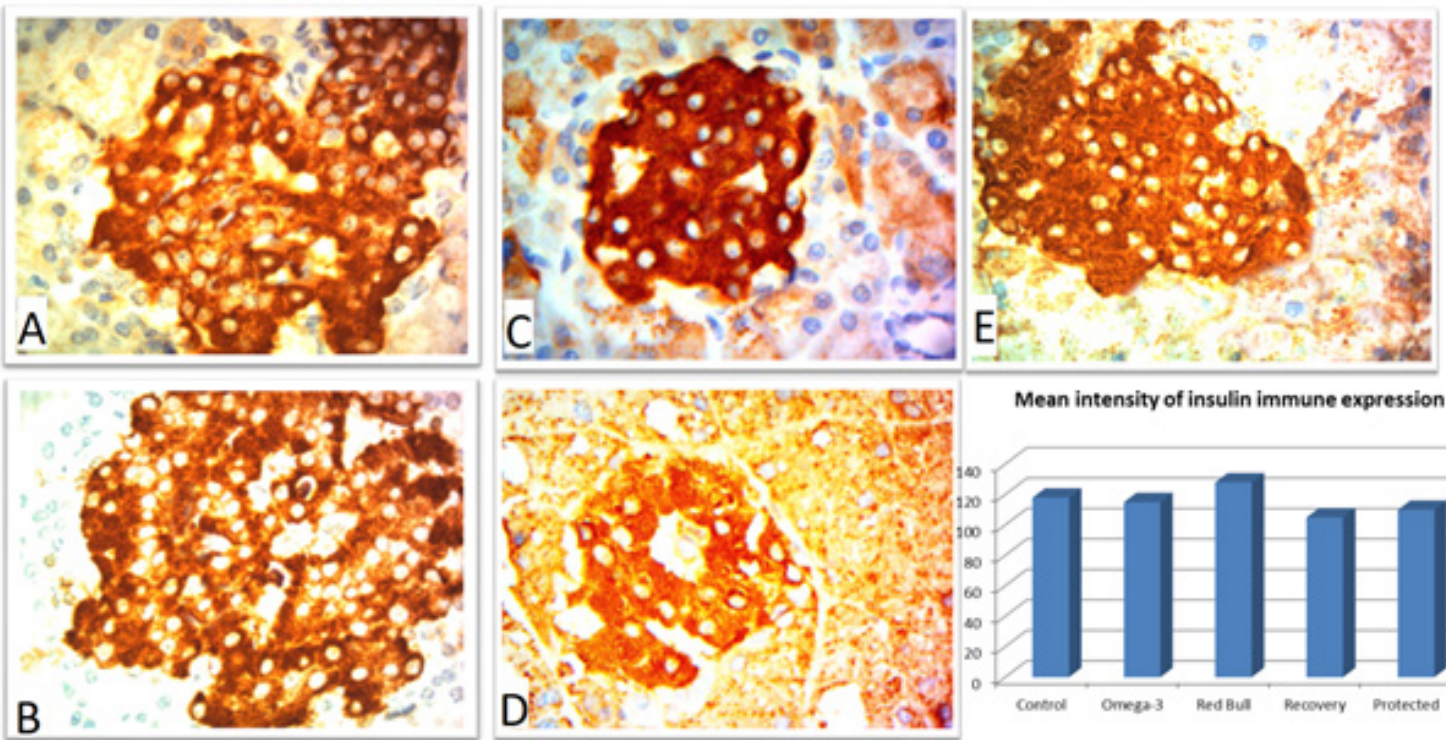

Mean intensity of insulin immune expression

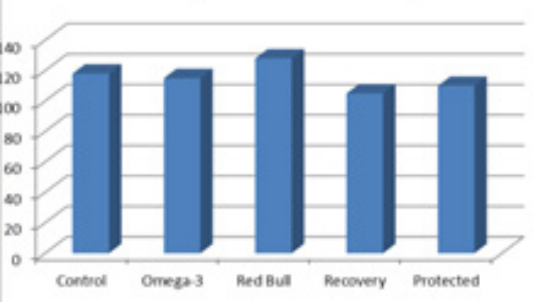

Fig. 6: Anti-insulin monoclonal antibody stained pancreatic sections of :

(A) Control group and (B) Omega-3 treated group showing moderately positive anti-insulin immune reaction.

(C) Energy drink treated group showing strongly positive immune reaction.

(D) Recovery group showing week positive immune reaction.

(E) Protected group showing moderately positive immune reaction. 
Table 1: Statistical means of body weight (gm) of various experimental groups

\begin{tabular}{lccc}
\hline Group & Mean $\pm \mathrm{SD}$ & $\begin{array}{c}\text { (Test of } \\
\text { significance) }\end{array}$ & P-value \\
\hline Group I (Control) & $180.3 \pm 6.4$ & & \\
Group II (Omega-3) & $183.9 \pm 5.1$ & 1.404 & 0.181 \\
Group IIIA (Red Bull) & $186.6 \pm 7.3$ & 2.086 & 0.055 \\
Group IIIB (Recovery) & $174.7 \pm 9.1$ & 1.611 & 0.128 \\
Group IV (Protected) & $184.2 \pm 4.9$ & 1.540 & 0.144 \\
$P$-value (Group IIIB versus Group IV $)$ & 1.540 & $(P>0.05)$ \\
\hline$P$ value $>0.05=$ Non
\end{tabular}

$P$ value $>0.05=$ Non significant.

$P$ value $<0.05=$ Significant.

$P$ value $<0.001=$ Highly significant.

Table 2: Statistical means of pancreatic weight (gm) of various experimental groups

\begin{tabular}{lccc}
\hline Group & Mean $\pm \mathrm{SD}$ & $\begin{array}{c}\text { (Test of } \\
\text { significance) }\end{array}$ & $\begin{array}{c}\text { P-value } \\
\text { (Versus } \\
\text { control) }\end{array}$ \\
\hline Group I (Control) & $0.5 \pm 0.1$ & & \\
Group II (Omega-3) & $0.6 \pm 0.1$ & 1.921 & 0.074 \\
Group IIIA (Red Bull) & $0.7 \pm 0.1$ & 3.884 & $0.001(>0.05)^{*}$ \\
Group IIIB (Recovery) & $0.4 \pm 0.1$ & 4.243 & $0.001(>0.05)^{*}$ \\
Group IV (Protected) & $0.6 \pm 0.1$ & 2.089 & 0.054 \\
$P$-value (Group IIIB versus Group IV ) & 6.397 & $0.001(>0.05)^{*}$ \\
\hline$P$ value $>0.05=$ Non significant. & & \\
$P$ value $<0.05=$ Significant. & & \\
$P$ value $<0.001=$ Highly significant. &
\end{tabular}

Table 3: Statistical means of blood glucose level (mg/dL) of various experimental groups

\begin{tabular}{|c|c|c|c|}
\hline Group & Mean \pm SD & $\begin{array}{c}\text { (Test of } \\
\text { significance) }\end{array}$ & $P$-value \\
\hline Group I (Control) & $112.4 \pm 5.6$ & & \\
\hline Group II (Omega-3) & $113.3 \pm 6.1$ & 0.450 & 0.659 \\
\hline Group IIIA (Red Bull) & $177.4 \pm 7.5$ & 28.079 & $0.000(>0.001)^{*}$ \\
\hline Group IIIB (Recovery) & $107.7 \pm 5.1$ & 1.808 & 0.091 \\
\hline Group IV (Protected) & $153.8 \pm 4.8$ & 21.682 & $0.000(>0.001)^{*}$ \\
\hline \multicolumn{2}{|c|}{$P$-value (Group IIIB versus Group IV ) } & 26.688 & $0.000(>0.001) *$ \\
\hline
\end{tabular}

$P$ value $>0.05=$ Non significant.

$P$ value $<0.05=$ Significant.

$P$ value $<0.001=$ Highly significant.

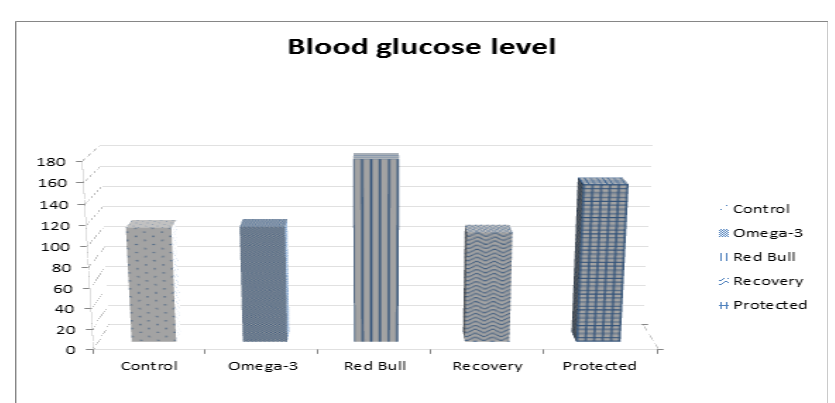

Diagram 1: Statistical means of blood glucose level $(\mathrm{mg} / \mathrm{dL})$ of various experimental groups

\section{DISCUSSION}

Energy drinks refers to dietetic food products in which the main source of energy are carbohydrates, whose energy value is not lesser than $80 \mathrm{~kJ} / 100 \mathrm{ml}(19 \mathrm{kcal} / 100 \mathrm{ml})$. The main active constituents of energy drinks include varying amounts of caffeine, guarana extract, taurine and ginseng. Also, additional amino acids, vitamins and carbohydrates are usually present. The intended effects of energy drinks are to provide sustenance and improve performance, concentration and endurance ${ }^{[16]}$.

The amounts of guarana, taurine, and ginseng found in popular energy drinks are far below the amounts expected to cause either therapeutic benefits or adverse events. However, caffeine and sugar are present in amounts known to cause a variety of adverse health effects ${ }^{[17]}$. There are increasing reports of caffeine intoxication from energy drinks, and it seems likely that problems with caffeine dependence and withdrawal will also increase. In children and adolescents who are not habitual caffeine users, vulnerability to caffeine intoxication may be markedly increased due to an absence of pharmacological tolerance ${ }^{[18]}$.

Among the fatty acids, it is the omega-3 polyunsaturated fatty acids (PUFA) which possess the most potent immunomodulatory activities, and among the omega-3 PUFA, those from fish oil eicosapentaenoic acid (EPA) and docosahexaenoic acid (DHA) - are more biologically potent than _linolenic acid (ALA). Some of the effects of omega-3 PUFA are brought about by modulation of the amount and types of eicosanoids made, and other effects are elicited by eicosanoid-independent mechanisms, including actions upon intracellular signaling pathways, transcription factor activity and gene expression ${ }^{[19]}$.

The present study revealed no significant differences in the body weight of animals administered energy drinks as compared to the control group. This could also be attributed to caffeine which intensifies metabolism and increases energy consumption. This is similar to the observation reported by Ebuehi et al ${ }^{[20]}$ and Ayuob and El Beshbeishy ${ }^{[15]}$.

Our study demonstrated that energy drinks administration led to a significant increase in blood glucose level simultaneously with strong positive immune reaction to anti insulin monoclonal antibody. This may indicate insulin resistance. This is in agreement with Ayuob and ElBeshbeishy ${ }^{[15]}$ who proved that the glucose level was increased in spite of elevated insulin. Also Joanna Sadowska ${ }^{[16]}$ reported increased concentration of glucose in blood plasma of the animals consuming the energy drink and characterized by a lower fat content in muscles, which may indicate developing insulin resistance.

This may be due to high amount of carbohydrates in addition to niacin that may affect carbohydrates metabolism. A can of Red Bull assures $100 \%$ of niacin RDA (Recommended Daily Allowance). This quantity is 
not usually seen as a risk, but it should be considered that high carbohydrate content of Red Bull may amplify niacin's side effects which include insulin resistance ${ }^{[21,22]}$. Zhou et $a l^{[23]}$ and $L i$ et $a l^{[24]}$ recorded that niacin supplementation in high carbohydrate diets may be one of the causes of diabetes.

In addition, consumption of high levels of sugar causes various detrimental effects on health, especially inducing insulin resistance, which is closely associated with the development of metabolic disorders such as obesity or type 2 diabetes ${ }^{[25,26]}$. Also, high levels of blood glucose may cause oxidative stress through the overproduction of reactive oxygen species (ROS) ${ }^{[26]}$. Under normal conditions, a natural system of scavengers called endogenous antioxidants counteracts the cytotoxicity of ROS produced from molecular oxygen in the mitochondria. Oxidative stress is the molecular and cellular damage resulting from excessive ROS production or from reduced endogenous antioxidants ${ }^{[27,28]}$. Also, Robertson ${ }^{[29]}$ reported that oxidative stress plays a key role in causing insulin resistance and $\beta$ eta cells dysfunction by their ability to activate stress sensitive signaling pathways. The pancreas may be more susceptible to oxidative stress than other tissues and organs because pancreatic islets cells show extremely weak manifestation of antioxidative enzymes ${ }^{[30]}$.

Furthermore, some studies have proved that caffeine may play an important role in the regulation of insulin release and related metabolic disorders. GonzálezDominguez et al ${ }^{[25]}$ showed that healthy young adults who consumed sugar-sweetened drinks with caffeine had a significant increase in blood glucose and insulin levels. This could be synergic effect of caffeine and sugar.

Also the metabolic effects observed after caffeine administration could result from its influence on the secretion of stress hormones, including adrenaline and cortisol which provide energy sources necessary to survive the stress. Both adrenaline and cortisol enhance lipolysis and increase plasma concentration of glucose. They additionally enhance gluconeogenesis and reduce peripheral glucose consumption by inhibiting the activity of glycolytic enzymes as a result of increasing the concentration of fatty acids in blood ${ }^{[16]}$.

In this study pancreatic sections of energy drink treated rats showed distorted architecture and variable degrees of acinar and islets' cells degeneration in the form of small pyknotic nuclei or even lost nuclei, intra cellular vacuolations, decreased zymogen granules, fatty deposition and dilated congested blood vessels. These changes are due to the interaction between the different contents of energy drink specially high content of caffeine which induces a pro-oxidant environment ${ }^{[15]}$. Similar changes have been observed by khayyat et al. ${ }^{[31]}$ on liver tissue after 4 weeks of energy drinks administration . Ayuob and El Beshbeishy ${ }^{[15]}$ reported similar changes on pancreas and stomach, also on the submandibular salivary glands as reported by Mubarak ${ }^{[32]}$.
The nuclear changes may be due to the preservatives added to the energy drinks as sodium benzoate which in combination with ascorbic acid, another common ingredient in energy drinks, they could form the chemical benzene, which is carcinogenic ${ }^{[32]}$. Congestion of blood vessels and infiltration of leucocytes might be due to different reaction of taurine associated with other active ingredients of the energy drinks as caffeine ${ }^{[31]}$.

In our study we observed that some ducts were dilated with retained secretion and degenerated epithelium this could be explained as Mubarak ${ }^{[32]}$ on her study of the effect of energy drink on the submandibular salivary glands as a sign of functional decline.

The thickened pancreatic septae with deposition of collagen fibers is due to the toxic effect of caffeine as reported by Takesue ${ }^{[33]}$ on his study on the effect of caffeine on wound healing of rat gingiva and revealed increased depositions of fibrin on the underlying connective tissue. These changes disappeared in recovery group due to cessation of the irritant, toxic effect of the energy drinks ${ }^{[34]}$.

The present study revealed that most of these finding were reversible after cessation of the energy drink. This is supported by Akande and Banjoko ${ }^{[34]}$ who reported that the damage done by excessive consumption of caffeinated energy drink is reversible as observed in the results of the blood chemistry analysis and the histopathological study of the organs of animals in the recovery group.

However, coadministration of Omega-3 with energy drink showed obvious protection of the pancreatic tissue against the hazardous effect of energy drink on pancreatic sections of rats. This may be attributed to its antiinflammatory and antioxidant activity of Omega- $3^{[15]}$.

Erayk et al. ${ }^{[35]}$ reported that Omega-3 fatty acids showed potential effects in lowering blood glucose levels and improving lipid profile and insulin resistance when it was used in combination with Pioglitazone through modulation of Toll-like receptor 4(TLR-4) in type 2 diabetes mellitus. Yuzuru Iizuka ${ }^{[36]}$ proved the protective effects of fish oil and pioglitazone on pancreatic tissue in obese $\mathrm{KK}$ mice with type 2 diabetes. The combined regimen significantly increased the percentage of $\beta$-cell area in the pancreatic islets, significantly decreased endoplasmic reticulum stress, and reduced the percentage of apoptotic cell death in the pancreatic islets. These findings suggest that fish oil and/or pioglitazone prevents $\beta$-cell dysfunction by improving the insulin resistance and decreasing the ER stress.

The anti-inflammatory aspects of Omega- 3 fatty acids is relative to prostaglandins and cytokines and their clinical effects in inflammatory and autoimmune diseases. It decreases production of prostaglandin E2 (PGE2) metabolites and increases prostacyclin PGI3, leading to an overall increase in total prostacyclin by increasing PGI3 without a decrease in PGI2 (both PGI2 and PGI3 are active vasodilators and inhibitors of platelet aggregation).Omega-3 also decreases thromboxane A2, 
a potent platelet aggregator and vasoconstrictor whilei ncreasing thromboxane A3, a weak platelet aggregator and a weak vasoconstrictor. Also, it decreases leukotriene B4 formation, an inducer of inflammation and a powerful inducer of leukocyte chemotaxis and adherence while increasing leukotriene B5, a weak inducer of inflammation and a weak chemotactic agent ${ }^{[19]}$.

The present study showed the toxic effects of energy drinks on pancreas and the protective effects of omega-3. More studies are recommended in the future to show the hazardous effects of energy drinks consumption on longer period of time and on different body organs.

\section{CONFLICTS OF INTEREST}

The authors have no conflicts of interest to declare.

\section{REFERENCES}

1. Heckman MA, Sherry K, De Mejia EG. Energy drinks: an assessment of their market size, consumer demographics, ingredient profile, functionality, and regulations in the United States. Comprehensive Reviews in food science and food safety. 2010 May;9(3):303-17.

2. Mubarak M. Effect of red bull energy drink on rats submandibular salivary glands (light and electron microscopic study). J Am Sci. 2012;8(1):366-72

3. Seifert SM, Schaechter JL, Hershorin ER, Lipshultz SE. Health effects of energy drinks on children, adolescents, and young adults. Pediatrics. 2011 Feb 14:peds-2009.

4. Portzky M, Audenaert K. The effects of energy drinks on cognitive performance. Tijdschrift voor psychiatrie. 2008;50(5):273-81.

5. Alford C, Cox H, Wescott R. The effects of red bull energy drink on human performance and mood. Amino acids. 2001 Sep 1;21(2):139-50.

6. Baum M, Weiss M. The influence of a taurine containing drink on cardiac parameters before and after exercise measured by echocardiography. Amino acids. 2001 Feb 1;20(1):75-82.

7. Seidl R, Peyrl A, Nicham R, Hauser E. A taurine and caffeine-containing drink stimulates cognitive performance and well-being. Amino acids. 2000 Nov 1;19(3-4):635-42.

8. Carvajal-Sancho A, Moncada-Jiménez J. The acute effect of an energy drink on the physical and cognitive performance of male athletes. Kinesiologia Slovenica. 2005;11(2):5-16.

9. Ballard SL, Wellborn-Kim JJ, Clauson KA. Effects of commercial energy drink consumption on athletic performance and body composition. The Physician and sportsmedicine. 2010 Apr 1;38(1):107-17.
10. Clauson KA, Shields KM, McQueen CE, Persad N. Safety issues associated with commercially available energy drinks. Journal of the American Pharmacists Association. 2008 May 1;48(3):e55-67.

11. Vivekanandarajah A, Ni S, Waked A. Acute hepatitis in a woman following excessive ingestion of an energy drink: a case report. Journal of medical case reports. $2011 \mathrm{Dec} ; 5(1): 227$.

12. Belluzzi A. N-3 fatty acids for the treatment of inflammatory bowel diseases. Proceedings of the Nutrition Society. 2002 Aug;61(3):391-5.

13. Ward OP, Singh A. Omega-3/6 fatty acids: alternative sources of production. Process Biochemistry. 2005 Dec 1;40(12):3627-52.

14. Delarue J, LeFoll C, Corporeau C, Lucas D. N-3 long chain polyunsaturated fatty acids: a nutritional tool to prevent insulin resistance associated to type 2 diabetes and obesity?. Reproduction Nutrition Development. 2004 May 1;44(3):289-99.

15. Ayuob N, ElBeshbeishy R. Impact of an Energy Drink on the Structure of Stomach and Pancreas of Albino Rat: Can Omega-3 Provide a Protection?. PloS one. 2016 Feb 19;11(2):e0149191.

16. Sadowska J. Evaluation of the effect of consuming an energy drink on the concentration of glucose and triacylglycerols and on fatty tissue deposition. A model study. Acta scientiarum polonorum. Technologia alimentaria. 2012 Jul 1;11(3).

17. Clauson KA, Shields KM, McQueen CE, Persad N. Safety issues associated with commercially available energy drinks. Journal of the American Pharmacists Association. 2008 May 1;48(3):e55-67.

18. Reissig CJ, Strain EC, Griffiths RR. Caffeinated energy drinks - a growing problem. Drug and alcohol dependence. 2009 Jan 1;99(1-3):1-0.

19. Simopoulos AP. Omega-3 fatty acids in inflammation and autoimmune diseases. Journal of the American College of nutrition. 2002 Dec $1 ; 21(6): 495-505$

20. Ebuehi OA, Ajayi OE, Onyeulor AL, Awelimobor D. Effects of oral administration of energy drinks on blood chemistry, tissue histology and brain acetylcholine in rabbits. Nigerian quarterly journal of hospital medicine. 2011;21(1):29-34.

21. Crisan M, Munteanu C, Rosioru C, Lang C. Red bull induces biochemical changes in Wistar rat liver. Annals of the Romanian Society for Cell Biology. 2013 Jul 1;18(2):118.

22. Chang AM, Smith MJ, Galecki AT, Bloem CJ, Halter JB. Impaired $\beta$-cell function in human 
aging: response to nicotinic acid-induced insulin resistance. The Journal of Clinical Endocrinology and Metabolism. 2006 Sep 1;91(9):3303-9.

23. Zhou SS, Li D, Zhou YM, Sun WP, Liu QG. B-vitamin consumption and the prevalence of diabetes and obesity among the US adults: population based ecological study. BMC Public Health. 2010 Dec;10(1):746.

24. Da Li WP, Zhou YM, Liu QG, Zhou SS, Luo N, Bian FN, Zhao ZG, Guo M. Chronic niacin overload may be involved in the increased prevalence of obesity in US children. World Journal of Gastroenterology: WJG. 2010 May $21 ; 16(19): 2378$

25. González Domínguez R, Mateos RM, Lechuga Sancho AM, González Cortés JJ, Corrales Cuevas M, Rojas Cots JA, Segundo C, Schwarz M. Synergic effects of sugar and caffeine on insulin mediated metabolomic alterations after an acute consumption of soft drinks. Electrophoresis. 2017 Sep;38(18):2313-22.

26. Nagai R, Shirakawa JI, Fujiwara Y, Ohno RI, Moroishi N, Sakata N, Nagai M. Detection of AGEs as markers for carbohydrate metabolism and protein denaturation. Journal of clinical biochemistry and nutrition. 2014;55(1):1-6.

27. Urunuela A, Sevillano S, De la Mano AM, Manso MA, Orfao A, De Dios I. Time-course of oxygen free radical production in acinar cells during acute pancreatitis induced by pancreatic duct obstruction. Biochimica et Biophysica Acta (BBA)-Molecular Basis of Disease. 2002 Nov 20;1588(2):159-64.

28. Hoidal JR. Reactive oxygen species and cell signaling. American journal of respiratory cell and molecular biology. 2001 Dec 1;25(6):661-3.

29. Robertson RP. Oxidative stress and impaired insulin secretion in type 2 diabetes. Current opinion in pharmacology. 2006 Dec 1;6(6):615-9.

30. Evans JL, Goldfine ID, Maddux BA, Grodsky GM. Are oxidative stress- activated signaling pathways mediators of insulin resistance and $\beta$-cell dysfunction?. Diabetes. 2003 Jan 1;52(1):1-8.

31. Khayyat L, Sorour JM, Essawy A, Al Rawi M. Histological, ultrastructural and physiological studies on the effect of different kinds of energy drinks on the liver of Wistar albino rat. International Journal of Research in Science. 2015 Sep 15;1(2):15-22.

32. Mubarak M. Effect of red bull energy drink on rats submandibular salivary glands (light and electron microscopic study). J Am Sci. 2012;8(1):366-72.

33. Takesue M. Effect of caffeine or $\mathrm{NaCl}$ on wound healing of the rat gingiva. Light and electron microscopic studies. Aichi Gakuin Daigaku Shigakkai Shi. 1989 Mar;27(1):277-316.

34. Akande IS, Banjoko OA. Assessment of biochemical effect of "Power Horse" energy drink on hepatic, renal and histological functions in sprague dawley rats. Annual Review and Research in Biology. 2011;1(3):45-56.

35. Eraky SM, Abdel-Rahman N, Eissa LA. Modulating effects of omega-3 fatty acids and pioglitazone combination on insulin resistance through toll-like receptor 4 in type 2 diabetes mellitus. Prostaglandins, Leukotrienes and Essential Fatty Acids. 2018 Sep 1;136:123-9.

36. Iizuka $\mathrm{Y}$, Kim H, Izawa $\mathrm{T}$, Sakurai $\mathrm{K}$, Hirako $\mathrm{S}$, Wada M, Matsumoto A. Protective effects of fish oil and pioglitazone on pancreatic tissue in obese KK mice with type 2 diabetes. Prostaglandins, Leukotrienes and Essential Fatty Acids (PLEFA). 2016 Dec 1;115:53-9. 
الملخص العربى

\section{التأثير التحسيني للأوميغا 3 على سمية البنكرياس المستحدثة بمشروبات الطاقة في ذكور الجرذان البيضاء 3}

\section{أسماء علي الاسوقي، أحمد أبو زيل، غادة حسن الصيفي، داليا عبد الرازق نوية قسم الأنسجة وبيولوجيا الخلية ـ كلية الطب - جامعة المنوفية}

المقدمة : تز ايد شعبية مشروبات الطاقة على مستوى العالم ونقص المعلومات حول آثار ها الخطرة المحتملة على الصحة مسألة مثيرة للجدل والبحث. الهدف من هذه الدراسة هو تقييم التأثير ات النسيجية والهستولوجية المناعية لمشروبات الطاقة على بنكرياس ذكور الجرذان البيضاء واحتمال التأثنير الوقائي للأوميغا س. المواد وطرق البحث: تم تقسيم •0 من ذكور الجرذان البيضاء بشكل عشو ائي إلى ؛ مجموعات. المجموعة الأولى (الضابطة). المجموعة الثانية (المعالجة أوميغا ץ) تم اعطاء الجرذان أوميغا ب بجر عة . . ب ملغ / كغ / يوم بالفم لمدة ع أسابيع. المجمو عة الثالثة (المعالجة بمشروب الطاقة) تلقت الجرذان ريد بول بجر عة ـ (ملغم / كغم / يوم بالفم لمدة

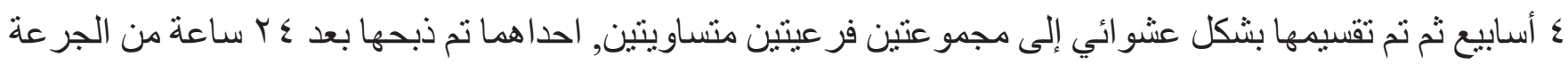
الأخيرة و الأخري تم تركها لمدة ع أسابيع بدون معالجة . المجموعة الرابعة (مجموعة أوميغا ب و ريد بول) تلقت

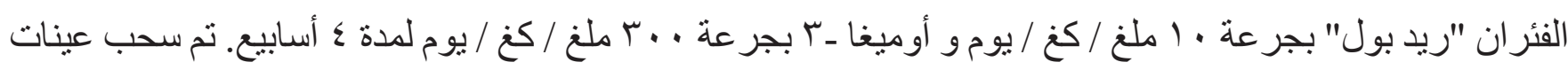
الدم للار اسة البيوكيميائية وتم ذبح الجرذان و إعداد عينات البنكرياس للار اسة النسيجية و الهستولوجية المناعية. النتائج: لم يكن لمشروب الطاقة تأثير واضح على وزن الحيوان ومع ذلك كان هناك زيادة كبيرة للغاية في وزن البنكرياس, وكذلك زيادة كبيرة في منوسط مستوى السكر في الدم في المجموعة المعالجة بالرغم من وجود علامات

$$
\text { تنشيطية على خلايا جزر لانجر هانز. }
$$

كثفت الدر اسات النسيجية و الهستولوجية المناعية علي البنكرياس عن عدة تأثير ات ضارة لمشروب الطاقة على نسيج البنكرياس وتم تحسن هذه التغييرات في مجموعة الاسترداد.و أظهر استخدام الأوميغا ب حماية ملحوظة للبنكرياس. الاستتتاج: إن إعطاء أوميغا 3 له تأثثير كبير على نسيج البنكرياس ضد التأثير ات الخطرة لمشروبات الطاقة 